\title{
TUNTUTAN PROVISI DALAM GUGATAN PELANGGARAN MEREK \\ PADA PENGADILAN NIAGA
}

Oleh:

\author{
Devi Marlita Martana
}

Mahasiswa Magister Ilmu Hukum Unud

\begin{abstract}
Act Number 15 Year 2001 regarding Trademark has set the provisional charges. Provisional charges may be filed by the plaintiff while the investigation process of trademark infringement lawsuit in court of commerce is still ongoing. In a civil proceeding, the provisional charge must not be the primary charge, however the provisional charge that is set out in the Trademark Act has already concerned the primary charge. Actions that can be requested in the provisional charge according to Article 78 paragraph (1) in the Trademark Act include cessation of production, cessation of circulation of goods and / or services using Plaintiff's trademark illegally. Using literature study that utilizes primary legal materials and secondary legal materials as the research object, the results of the discussion are expected to be based on sufficient arguments to provide benefits for those who are interested to learn the trademark law enforcement.
\end{abstract}

Key Words: provisional charge, trademark infringement lawsuit, court of commerce

\section{PENDAHULUAN}

\section{Latar Belakang}

Tuntutan provisi kerap digunakan oleh Penggugat untuk mencegah kerugian yang lebih besar. Permohonan provisi sangat umum diajukan dalam proses penyelesaian sengketa perdata di Pengadilan Negeri. Ternyata pada penyelesaian sengketa merek di Pengadilan Niaga terdapat pula ketentuan mengenai tuntutan provisi yang dapat diajukan oleh Penggugat selama pemeriksaan gugatan pelanggaran merek. Gugatan pelanggaran merek dapat diajukan kepada Pengadilan Niaga menyangkut 2 (dua) hal yakni gugatan ganti rugi dan/atau penghentian semua perbuatan yang berkaitan dengan penggunaan merek tersebut.

Ketentuan mengenai tuntutan provisi dalam Undang-Undang Nomor 15 Tahun 2001 tentang Merek (selanjutnya disebut UU Merek) diletakkan pada Pasal 78 ayat (1). Ketentuan Pasal 78 ayat (1) UU Merek menentukan bahwa Hakim dapat memerintahkan Tergugat untuk menghentikan produksi, peredaran dan/atau perdagangan barang atau jasa 
yang menggunakan merek milik Penggugat secara tanpa hak. Keputusan Hakim untuk menghentikan kegiatan Tergugat terkait penggunaan merek secara tanpa hak tersebut didasarkan pada permohonan Penggugat sebagai pemilik atau penerima lisensi merek. Akan tetapi, Pengadilan Niaga yang berwenang mengadili sengketa gugatan pelanggaran merek belum memiliki hukum acaranya sendiri. Oleh karena itu, beberapa hal terkait proses beracara di Pengadilan Niaga masih berpedoman pada prinsipprinsip hukum acara perdata yang digunakan di Pengadilan Negeri. Salah satu prinsip hukum acara perdata mengenai tuntutan provisi adalah isi tuntutan yang tidak boleh menyangkut pokok perkara. Hal-hal tersebut memunculkan isu terkait keselarasan ketentuan tuntutan provisi dalam UU Merek dengan ketentuan yang ada dalam sumber hukum acara perdata. Untuk itu, dalam pembahasan akan dibahas mengenai konsep tuntutan provisi dalam hukum acara perdata, sejauh mana hukum acara perdata digunakan dalam penyelesaian sengketa di Pengadilan Niaga dan yurisprudensi Pengadilan Niaga terkait tuntutan provisi dalam gugatan pelanggaran merek.

\section{Rumusan Masalah}

Adapun rumusan masalah yang akan dibahas pada penelitian ini adalah sebagai berikut: "Bagaimana sikap Hakim dalam memberikan putusan terhadap tuntutan provisi yang sesuai dengan ketentuan Pasal 78 ayat (1) UU Merek?"

\section{Tujuan Penelitian}

Penelitian ini dilakukan untuk mendalami hukum acara Pengadilan Niaga, secara khusus untuk mengetahui pengaturan mengenai tuntutan provisi terkait gugatan pelanggaran merek dan yurisprudensi Pengadilan Niaga terkait hal tersebut.

\section{METODE PENELITIAN}

Penelitian ini menggunakan metode penelitian hukum normatif berupa studi kepustakaan / dokumen yang menggunakan bahan hukum primer dan sekunder ${ }^{1}$ sebagai objek penelitian.

\section{HASIL DAN PEMBAHASAN}

\section{Tuntutan Provisi Pada Perkara Perdata}

Tuntutan provisi yang sering juga disebut gugatan provisi merupakan salah satu asesor dari gugatan pokok yang berisi permintaan agar pengadilan mengeluarkan suatu keputusan sementara yang memerintahkan dilakukan suatu tindakan yang sifatnya sementara sampai gugatan

\footnotetext{
1 Bambang Waluyo, 1991, Penelitian Hukum dalam Praktek, Sinar Grafika, Jakarta, hal. 13.
} 
pokoknya memperoleh putusan akhir.

Karena sifatnya yang asesor terhadap gugatan pokok, maka tuntutan provisi tidak dapat diajukan tanpa adanya gugatan pokok. Tuntutan provisi dapat diajukan bersamaan maupun terpisah dengan gugatan pokok, tetapi pada umumnya tuntutan provisi dicantumkan sekaligus di dalam surat gugatan. ${ }^{2}$

Tuntutan provisi harus memenuhi syarat formil, yakni ${ }^{3}$ :

a. Memuat alasan diajukan tuntutan provisi termasuk urgensi dan relevansinya dengan gugatan pokok

b. Mengemukakan dengan jelas tindakan sementara yang dimohonkan

c. Tindakan yang dimohonkan tidak boleh mengenai pokok perkara

Jika terdapat tuntutan provisi dalam proses pemeriksaan gugatan, maka pemeriksaan gugatan pokok akan ditangguhkan. Hakim akan mendahulukan pemeriksaan tuntutan provisi menggunakan prosedur singkat atau kilat. Meskipun dimaksudkan untuk diputus hari itu juga, namun Pasal 285 RV memungkinkan penundaan pemeriksaan tuntutan provisi apabila penundaan

\footnotetext{
2 M. Yahya Harahap, 2008, Hukum Acara Perdata tentang Gugatan, Persidangan, Penyitaan, Pembuktian dan Putusan Pengadilan, Cet. 8, Sinar Grafika, Jakarta, hal. 884-885.

${ }^{3}$ Ibid, hal. 885.
}

tersebut tidak menyebabkan terjadinya kerugian yang besar atau kerugian yang tidak dapat diperbaiki. ${ }^{4}$

Keputusan pengadilan atas tuntutan provisi disebut putusan provisi. Putusan provisi ini merupakan salah satu jenis putusan sela, yakni putusan yang mendahului putusan akhir. Putusan provisi diberikan agar dapat dilakukan tindakantindakan sementara yang dapat menjamin kepentingan salah satu atau kedua belah pihak. ${ }^{5}$ Pengaturan putusan provisi antara lain terdapat dalam Pasal 180 ayat (1) HIR yang mengatur sebagai berikut:

"Biarpun orang membantah keputusan hakim atau meminta banding, pengadilan boleh memerintahkan supaya keputusan hakim itu dijalankan dulu, jika ada suatu tanda alas hak yang otentik atau suatu surat yang menurut peraturan boleh diterima sebagai bukti, atau jika ada keputusan hukuman lebih dahulu dengan keputusan hakim yang sudah memperoleh kekuatan hukum yang pasti, atau jika dikabulkan tuntutan sementara pula dalam hal perselisihan besit."

Berdasarkan ketentuan Pasal 180 ayat (1) HIR tersebut, putusan provisi dapat dijalankan terlebih dahulu walaupun gugatan pokok belum diputus, sebab padanya melekat putusan serta merta (uitvoerbaar bij voorraad). Akan tetapi

\footnotetext{
${ }^{4}$ Ibid.

${ }^{5}$ Abdul Manan, 2005, Penerapan Hukum Acara Perdata di Lingkungan Peradilan Agama, Kencana, Jakarta, hal. 49.
} 
Pasal 286 RV juga menentukan bahwa "putusan-putusan yang segera harus dilaksanakan tidak membawa kerugian kepada perkara pokoknya”. Untuk itu hakim mempunyai tiga pilihan dalam memutus tuntutan provisi tersebut ${ }^{6}$ :

a. Menyatakan tuntutan atau gugatan provisi tidak dapat diterima

Tuntutan provisi tidak dapat diterima apabila tidak memenuhi syarat formil.

b. Menyatakan menolak gugatan provisi

Tuntutan provisi harus ditolak oleh hakim apabila tidak ada urgensi maupun relevansinya dengan gugatan pokok, sehingga tindakan sementara yang dimohonkan tidak perlu dilakukan.

c. Menyatakan mengabulkan gugatan provisi

Tuntutan provisi dikabulkan apabila: Pertama, memenuhi syarat formil. Kedua, alasan yang diajukan sebagai dasar tuntutan memiliki relevansi dan urgensi terkait gugatan pokok. Ketiga, jika tindakan sementara yang dimohonkan tidak dilakukan, akan timbul kerugian yang sangat besar.

\section{Pembentukan dan Wewenang}

\section{Pengadilan Niaga}

\footnotetext{
${ }^{6}$ M. Yahya Harahap, Op. Cit., hal. 885-886.
}

Pasal 76 ayat (2) UU Merek menentukan bahwa gugatan pelanggaran merek diajukan kepada Pengadilan Niaga. Gugatan pelanggaran merek tersebut dapat diajukan oleh penerima lisensi merek terdaftar baik secara sendiri-sendiri maupun bersama-sama dengan pemilik merek bersangkutan (Pasal 77 UU Merek). Pembentukan pengadilan niaga menjadi salah satu hal yang direkomendasikan IMF untuk diatur dalam peraturan perundangundangan di bidang kepailitan. IMF memberi batas waktu pembentukan Pengadilan Khusus Tata Niaga sampai tanggal 20 Agustus 1998 karena lambatnya penyelesaian utang di Indonesia saat itu tidak membantu dalam pemulihan ekonomi yang sedang diupayakan oleh pemerintah. $^{7}$ Untuk itu FaillissementsVerordening atau Undang-Undang tentang Kepailitan yang termuat dalam Staatsblad Tahun 1905 Nomor 217 juncto Staatsblad Tahun 1906 Nomor 348 dirubah dengan Perpu Nomor 1 Tahun 1998 tentang Perubahan atas Undang-Undang tentang Kepailitan. Perpu Nomor 1 Tahun 1998 diundangkan pada tanggal 22 April 1998 dan pada 9 September 1998 ditetapkan menjadi undang-undang berdasarkan Undang-Undang Nomor 4 Tahun 1998.

\footnotetext{
7 Andi Muhammad Asrun, A. Prasetyantoko, dkk , 2000, Analisa Yuridis dan Empiris Peradilan Niaga, Centre for Information \& Law - Economic Studies (CINLES), Jakarta, hal. 10-11.
} 
Perpu Nomor 1 Tahun 1998 tersebut sudah memuat ketentuan mengenai Pengadilan Niaga. Pasal 280 ayat 1 Perpu Nomor 1 Tahun 1998 menentukan: "Permohonan pernyataan pailit dan penundaaan kewajiban pembayaran utang sebagaimana dimaksud dalam BAB PERTAMA dan BAB KEDUA, diperiksa dan diputuskan oleh Pengadilan Niaga yang berada di lingkungan Peradilan Umum." Peradilan Umum merupakan salah satu dari 4 lingkungan peradilan yang berada di bawah Mahkamah Agung. Pasal 24 ayat (2) Undang Undang Dasar Negara Republik Indonesia Tahun 1945 (selanjutnya disebut UUD NRI 1945) menetapkan bahwa kekuasaan kehakiman dilakukan oleh sebuah Mahkamah Agung dan badan peradilan yang berada di bawahnya dalam lingkungan peradilan umum, lingkungan peradilan agama, lingkungan peradilan militer, lingkungan peradilan tata usaha negara, dan oleh sebuah Mahkamah Konstitusi.

Keberadaan Pengadilan Niaga dalam lingkungan Peradilan Umum dimungkinkan karena dalam Pasal 8 ayat (1) Undang Undang No. 2 Tahun 1986 tentang Peradilan Umum juncto UndangUndang No. 8 Tahun 2004 tentang Perubahan Atas Undang-Undang Nomor 2 Tahun 1986 tentang Peradilan Umum juncto Undang-Undang No. 49 Tahun
2009 tentang Perubahan Kedua Atas Undang-Undang Nomor 2 Tahun 1986 tentang Peradilan Umum ditentukan bahwa di lingkungan peradilan umum dapat dibentuk pengadilan khusus yang diatur dengan undang-undang. Keberadaan Pengadilan Niaga adalah sebagai salah satu pengadilan khusus di lingkungan peradilan umum. Pasal 281 Perpu Nomor 1 Tahun 1998 menetapkan: "Untuk pertama kali dengan undang-undang ini, Pengadilan Niaga dibentuk pada Pengadilan Negeri Jakarta Pusat”.

Pengadilan Niaga berwenang untuk memeriksa dan memutus perkara pada tingkat pertama dengan hakim majelis (Pasal 282 ayat (1) Perpu Nomor 1 Tahun 1998). Ketentuan mengenai kompetensi absolut pengadilan niaga dapat ditemukan dalam Pasal 280 ayat (2) Perpu Nomor 1 Tahun 1998. Pasal 280 ayat (2) Perpu Nomor 1 Tahun 1998 menentukan:

"Pengadilan Niaga sebagaimana dimaksud dalam ayat (1), selain memeriksa dan memutuskan permohonan pernyataan pailit dan penundaan kewajiban pembayaran utang, berwenang pula memeriksa dan memutuskan perkara lain di bidang perniagaan yang penetapannya dilakukan dengan Peraturan Pemerintah".

Kewenangan absolut Pengadilan Niaga memang pada mulanya hanya memeriksa dan memutuskan permohonan pernyataan pailit dan penundaan kewajiban pembayaran utang, namun kini 
kewenangan absolut Pengadilan Niaga berkembang juga menjadi kewenangan untuk memeriksa dan memutuskan perkara perniagaan lainnya seperti perkara hak cipta, hak paten dan juga hak merek. ${ }^{8}$

Sampai saat ini Pengadilan Niaga belum diatur secara tersendiri dalam satu bentuk peraturan perundang-undangan. Peraturan mengenai Pengadilan Niaga masih tersebar ke dalam berbagai peraturan perundang-undangan. Selain dalam UU Kepailitan, peraturan mengenai Pengadilan Niaga juga dapat ditemukan antara lain dalam Undang-Undang Nomor 30 Tahun 2000 tentang Desain Tata Letak Sirkuit Terpadu, Undang-Undang Nomor 14 Tahun 2001 tentang Paten, UndangUndang Nomor Desain Industri, UU Merek dan Undang-Undang Nomor 19 Tahun 2002. Kelima undang-undang tersebut mengatur bahwa gugatan pelanggaran maupun gugatan pembatalan pendaftaran Desain Tata Letak Sirkuit Terpadu, Paten, Desain Industri, Merek dan Hak Cipta diajukan ke pengadilan niaga. Dengan begitu kewenangan pengadilan niaga menjadi diperluas, tidak hanya menangani perkara kepailitan dan penundaan kewajiban pembayaran utang tetapi juga menangani perkara-perkara dibidang HKI. Perluasan kewenangan

\footnotetext{
${ }^{8}$ M. Hadi Shubhan, 2009, Hukum Kepailitan: Prinsip, Norma, dan Praktik di Peradilan, Kencana, Jakarta, hal. 103.
}

pengadilan niaga tersebut dilakukan agar pengadilan niaga dapat menjadi pengadilan niaga (commercial court) dalam arti yang seluas-luasnya yang dapat memeriksa dan memutus berbagai perkara dalam masalah perniagaan. ${ }^{9}$

\section{Problematika Upaya Hukum}

\section{Tuntutan Provisi dalam Gugatan}

\section{Pelanggaran Merek}

Ketiadaan pengaturan yang dibuat tersendiri berkaitan dengan Pengadilan Niaga meliputi pengaturan mengenai hukum acara yang berlaku di Pengadilan Niaga. Beberapa hal terkait penyelesaian sengketa di Pengadilan Niaga masih tersebar dalam undang-undang yang mengatur kepailitan dan HKI, salah satunya terdapat dalam Pasal 284 ayat (1) Perpu Nomor 1 Tahun 1998 yang menentukan bahwa "Kecuali ditentukan lain dengan undang-undang, hukum acara perdata yang berlaku diterapkan pula pada Pengadilan Niaga".

Terkait dengan hukum acara di Pengadilan Niaga tersebut, ada tiga pendapat mengenai hukum acara yang dipergunakan untuk menyelesaikan perselisihan yang timbul sehubungan dengan pendaftaran merek dan/atau

9 Tata Wijayanta, 2009, Kajian tentang Kompetensi Absolut Pengadilan Niaga, Jurnal Ilmu Hukum Litigasi, Volume 10 Nomor 1 Pebruari 2009, hal. 16. 
pelanggaran merek yang terungkap dalam

Seminar yang diselenggarakan oleh Tim

Pengarah Pengadilan Niaga - BAPPENAS

di Jakarta tanggal 30 Agustus 2001, yaitu:

a. Pertama adalah pendapat bahwa proses dan tata cara beracara di Pengadilan Niaga tunduk pada ketentuan yang diatur dalam Het Herziene Indonesisch Reglement (HIR), Rechtsreglement Buitengewesten $(\mathrm{RBg})$, atau Reglement op de Rechsvorerdering (Rv);

b. Pendapat yang kedua adalah dapat diberlakukannya hukum acara yang berlaku untuk proses kepailitan sebagaimana diatur dalam UndangUndang tentang Kepailitan;

c. Dan yang ketiga adalah pendapat bahwa perlunya dibentuk suatu ketentuan baru yang berdiri sendiri, yakni yang mengatur secara khusus bagaimana proses beracara di Pengadilan Niaga. ${ }^{10}$

Sebagai bagian dari peradilan umum yang secara khusus berwenang memeriksa dan memutuskan sengketa perniagaan tertentu, terdapat beberapa upaya hukum yang khusus hanya ada dalam proses penyelesaian sengketa di Pengadilan Niaga, seperti permohonan penetapan

${ }^{10}$ Gunawan Widjaja, 2001, Undang-Undang Merek No. 15 Tahun 2001: Beberapa Hal Baru yang Diatur di Dalamnya, Law Review, Fakultas Hukum Universitas Pelita Harapan, Jakarta, hal. 147. sementara untuk dugaan pelanggaran merek, desain industri, hak cipta dan paten. Akan tetapi kebanyakan upaya hukum yang digunakan oleh para pihak yang berperkara di Pengadilan Niaga merupakan upaya hukum yang telah lebih dulu digunakan dalam penyelesaian perkara di Pengadilan Negeri, seperti tuntutan provisi. Dengan melihat kembali ketentuan Pasal 284 ayat (1) Perpu No. 1 Tahun 1998, ketentuan mana yang cenderung digunakan oleh hakim Pengadilan Niaga. Sebab terdapat konflik antara norma mengenai tuntutan provisi pada hukum acara perdata dengan norma mengenai tuntutan provisi yang terdapat dalam UU Merek.

Tuntutan provisi pada UU Merek diatur dalam Pasal 78. Pasal 78 UU Merek tersebut mengatur sebagai berikut:

(1) Selama masih dalam pemeriksaan dan untuk mencegah kerugian yang lebih besar, atas permohonan pemilik Merek atau penerima Lisensi selaku penggugat, hakim dapat memerintahkan tergugat untuk menghentikan produksi, peredaran dan/atau perdagangan barang atau jasa yang menggunakan Merek tersebut secara tanpa hak.

(2) Dalam hal tergugat dituntut juga menyerahkan barang yang menggunakan Merek secara tanpa hak, hakim dapat memerintahkan bahwa penyerahan barang atau nilai barang tersebut dilaksanakan setelah putusan pengadilan mempunyai kekuatan hukum tetap. 
Upaya hukum tuntutan provisi yang diatur dalam Pasal 78 UU Merek ini sering diajukan oleh Penggugat untuk menjamin kepentingannya yang dimohonkan dalam gugatan pokok. Adapun inti dari tuntutan provisi yang dapat dimohonkan dalam kaitannya dengan gugatan pelanggaran merek adalah meminta hakim untuk menghentikan segala kegiatan yang menggunakan barang atau jasa yang menggunakan merek milik Penggugat secara tanpa hak sebagaimana diatur dalam Pasal 78 ayat (1) UU Merek.

Penggugat selaku pemilik atau penerima lisensi merek diperkenankan juga untuk memohon agar diserahkannya barang yang menggunakan merek tanpa hak melalui tuntutan provisi ini, akan tetapi Pasal 78 ayat (2) memberi suatu dorongan bagi hakim dalam mengambil keputusan agar sebaiknya penyerahan barang dilakukan setelah gugatan pokok memperoleh putusan yang telah berkekuatan hukum tetap. Penundaan penyerahan barang tersebut dilakukan untuk melindungi hak Tergugat selama belum ada kepastian mengenai perkara pokok.

\section{Pasal 76 ayat (1) UU Merek} menentukan bahwa:

"Pemilik Merek terdaftar dapat mengajukan gugatan terhadap pihak lain yang secara tanpa hak menggunakan
Merek yang mempunyai persamaan pada pokoknya atau keseluruhannya untuk barang atau jasa yang sejenis berupa:

a. gugatan ganti rugi, dan/atau

b. penghentian semua perbuatan yang berkaitan dengan penggunaan Merek tersebut."

Bandingkan ketentuan Pasal 76 ayat (1) tersebut dengan ketentuan Pasal 78 ayat (1) UU Merek. Keduanya sama-sama mengatur mengenai gugatan atau tuntutan yang sama dan saling berkaitan. Pasal 76 ayat (1) UU Merek mengatur mengenai gugatan pokok, sedangkan Pasal 78 ayat (1) UU Merek mengatur mengenai gugatan / tuntutan provisi yang sangat bergantung pada adanya gugatan pokok.

Salah satu syarat formil tuntutan provisi adalah tindakan yang dimohonkan tidak boleh mengenai pokok perkara. Apa yang dapat dituntut secara provisi berdasarkan Pasal 78 ayat (1) UU Merek merupakan cakupan tindakan yang dapat dimohonkan melalui gugatan pokok pelanggaran merek mengenai penghentian semua perbuatan yang berkaitan dengan penggunaan merek (Pasal 76 ayat (1) huruf b UU Merek). Tuntutan provisi sesuai Pasal 78 ayat (1) UU Merek dengan demikian sudah menyangkut pokok perkara dan berdasarkan prinsip hukum acara perdata bertentangan dengan Pasal 76 ayat (1) huruf b UU Merek. Jika Hakim berpedoman pada prinsip-prinsip hukum 
acara perdata makan tuntutan provisi yang demikian tidak dapat diterima oleh Hakim.

Sudah banyak tuntutan provisi yang diajukan oleh Penggugat dalam kaitannya dengan gugatan pelanggaran merek. Salah satunya adalah perkara Nomor 55 / MEREK / 2007 / PN NIAGA Jkt.Pst di mana H. ELON DACHLAN mengajukan gugatan pelanggaran merek terhadap PT BANK PEMBANGUNAN DAERAH SUMATERA SELATAN (BANK SUMSEL). H. ELON DACHLAN selaku Penggugat mengajukan petitum sebagai berikut:

\section{Dalam Provisi:}

- Untuk mencegah kerugian Penggugat yang lebih besar karena Tergugat sampai saat ini tanpa hak tetap menggunakan merek "TASBIH" milik Penggugat, maka selama perkara ini masih dalam pemeriksaan, mohon Majelis Hakim Pengadilan Niaga pada Pengadilan Negeri Jakarta Pusat memutuskan terlebih dahulu memerintahkan Tergugat untuk menghentikan perdagangan barangatau jasa tabungan untuk ibadah haji yang menggunakan merek "TASBIH" ;

\section{Dalam Pokok Perkara :}

1. Menerima dan mengabulkan gugatan Penggugat untuk seluruhnya ;

2. Menguatkan putusan provisi ;

3. Menyatakan bahwa Penggugat adalah pemilik merek "TASBIH" yang sah berdasarkan hukum ;

4. Menyatakan bahwa tindakan Tergugat ... merupakan pelanggaran merek dan bertentangan dengan hukum adalah tidak mempunyai kekuatan hukum ;
5. Menghukum Tergugat untuk membayar ganti rugi kepada Penggugat ...;

6. Menghukum Tergugat untuk membayar uang paksa ... ;

7. Menghukum Tergugat menghentikan segala tindakan pemakaian yang bertujuan untuk memproduksi, memperdagangkan / menjual jenis barang / jasa tabungan untuk biaya ibadah haji yang menggunakan merek "TASBIH" milik Penggugat ;

8. Menyatakan putusan perkara ini dapat dijalankan terlebih dahulu, meskipun terhadap putusan tersebut diajukan suatu upaya hukum ;

9. Menghukum Tergugat untuk membayar semua biaya perkara ini ; atau :

Apabila Majelis Hakim Niaga yang memeriksa dan mengadili perkara ini berpendapat lain, mohon kiranya agar dapat memberikan putusan yang seadiladilnya (ex aequo et bono)

Hakim pemeriksa perkara menjatuhkan putusan menolak tuntutan provisi dengan pertimbangan bahwa tuntutan tersebut sudah menyangkut materi / pokok perkara yang akan dibuktikan nantinya dalam pemeriksaan pokok perkara dan pertimbangan adanya kemungkinan Tergugat mengalami kerugian apabila Penggugat tidak dapat membuktikan dalilnya. Putusan provisi tersebut dikuatkan oleh Mahkamah Agung dalam kasasi melalui putusan Nomor $123 \mathrm{~K} /$ Pdt.Sus / 2008 dengan mempertimbangkan bahwa judex facti yang menolak tuntutan provisi sudah tepat dan benar karena penghentian suatu produk yang digunakan oleh Tergugat harus terlebih dahulu 
ditentukan bahwa penggunaan tersebut tidak sah yang harus ditentukan dalam pokok perkara.

Pertimbangan serupa juga diberikan sebagai alasan penolakan hakim atas tuntutan provisi pada perkara gugatan pelanggaran merek Nomor 05/Merk/2002/PN.Niaga.JKT.PST.

Penggugat mengajukan tuntutan dalam provisi agar Hakim memerintahkan Tergugat II untuk menghentikan penggunaan merek 'Menara" untuk produksi sabun detergent yang dibuatnya sejak putusan provisi ini dijatuhkan sampai putusan perkara ini berkekuatan hukum tetap dengan ancaman dwangsom untuk setiap pelanggaran terhadap putusan provisi. Akan tetapi Hakim berpendapat bahwa tindakan yang dimohonkan oleh Penggugat telah memasuki materiil pokok perkara, sehingga perlu dibuktikan lebih lanjut ada tidaknya alasan hukum yang relevan sesuai dalil Penggugat dalam gugatannya tentang perbuatan melanggar merek yang dilakukan oleh Tergugat.

Putusan Hakim untuk menolak tuntutan provisi pada perkara-perkara pelanggaran merek di atas meskipun pengaturan provisi telah diatur dalam UU Merek dapat dibenarkan karena Hakim sebagai pelaksana kekuasaan kehakiman memiliki kebebasan relatif dalam menerapkan hukum. Salah satu bentuk kebebasan relatif yang dapat digunakan oleh Hakim adalah dengan mengutamakan penerapan yurisprudensi ${ }^{11}$. Salah satu syarat putusan pengadilan dapat dikualifikasikan sebagai yurisprudensi adalah putusan tersebut secara konstan diikuti oleh putusan-putusan setelahnya. Putusan tersebut diikuti secara konstan karena dianggap memuat dasar-dasar kebenaran dan prinsip keadilan umum yang membuatnya seolah-olah mengikat untuk diikuti oleh putusan-putusan setelahnya dalam kasus serupa. ${ }^{12}$ Untuk contoh perkara pelanggaran merek di atas, terdapat banyak putusan yang menolak tuntutan provisi dalam gugatan pelanggaran merek karena memohon tindakan yang menyangkut pokok perkara. Selain Perkara Nomor 05/Merk/2002/PN.Niaga.JKT.PST dan perkara Nomor 55 / MEREK / 2007 / PN NIAGA Jkt.Pst terdapat juga perkara Nomor 19/Merek/2004/PN.Niaga.Jkt.Pst dan perkara Nomor 20/Merek/2003/PN.Niaga.Jkt.Pst. Adapun yurisprudensi berfungsi untuk ${ }^{13}$ :

a. Memantapkan standar hukum

b. Membuat suatu landasan dan persepsi hukum yang sama

c. Menciptakan kepastian penegakan hukum

d. Mencegah putusan berdisparitas

\footnotetext{
${ }^{11}$ M. Yahya Harahap, Op. Cit., hal. 867.

${ }^{12}$ M. Yahya Harahap, Op. Cit., hal. 833.

${ }^{13}$ M. Yahya Harahap, Op. Cit., hal. 835-837.
} 
Umumnya di negara-negara civil law yurisprudensi tidak harus diikuti oleh hakim dalam memutus perkara serupa yang ada di kemudian hari, berbeda halnya dengan negara-negara common $\operatorname{law}^{14}$. Di Indonesia, putusan hanya mengikat para pihak, tetapi di negara-negara yang menganut asas the binding force of precedent putusan tidak hanya mengikat para pihak tetapi juga mengikat hakim ${ }^{15}$.

Hakim dalam memberikan putusan dapat juga melakukan suatu pertimbangan atas dasar doktrin hukum. Doktrin hukum merupakan salah satu sumber hukum di samping peraturan perundang-undangan, kebiasaan, yurisprudensi, dan traktat ${ }^{16}$. Akan tetapi doktrin hukum dapat menjadi kaidah hukum atas dasar pendapat bahwa doktrin hukum yang merupakan pendapat ahli hukum dapat disamakan dengan putusan pengadilan. Oleh karena itu, penggunaan doktrin hukum dalam pertimbangan putusan dapat dibenarkan. Doktrin hukum yang dapat digunakan oleh Hakim sebagai dasar pertimbangan putusan adalah doktrin hukum yang mempunyai otoritas sebagai sumber hukum, yakni pendapat yang umum dan

\footnotetext{
${ }^{14}$ Abdulkadir Muhammad, 2008, Hukum Acara Perdata Indonesia, PT Citra Aditya Bakti, Bandung, hal. 161.

${ }^{15}$ Sudikno Mertokusumo, 1982, Hukum Acara Perdata Indonesia, Liberty, Yogyakarta, hal. 162.

${ }^{16}$ Dudu Duswara Machmudin, 2010, Pengantar Ilmu Hukum: Sebuah Sketsa, Refika Aditama, Bandung, hal. 79.
}

diterima secara luas oleh para profesional. ${ }^{17}$ Tidak dapat diterimanya tuntutan provisi yang menyangkut pokok perkara termasuk salah satu doktrin hukum yang mempunyai otoritas dan dapat dijadikan sebagai dasar pertimbangan hakim dalam mengambil putusan karena secara luas telah diterima oleh para ahli hukum. Hakim pemeriksa perkara Nomor 20/Merek/2003/PN.Niaga.Jkt.Pst juga menggunakan doktrin hukum tersebut dalam mempertimbangkan tuntutan provisi yang diajukan Penggugat. Hakim pemeriksa perkara Nomor 20/Merek/2003/PN.Niaga.Jkt.Pst

menggunakan pendapat mengenai tuntutan dan putusan provisi yang diajukan oleh Prof. Dr. RM Sudikno Mertokusumo SH, Ny. Retnowulan Sutanto SH, Lilik Mulyadi SH, Olden Bidara SH, dan Ridwan Syahrani SH.

\section{SIMPULAN DAN SARAN}

\section{Simpulan}

Ketiadaan pengaturan yang tersendiri mengenai Pengadilan Niaga menimbulkan perbedaan pendapat terkait hukum acara yang seharusnya digunakan. Tuntutan provisi untuk menghentikan produksi, peredaran dan/atau perdagangan barang atau jasa yang menggunakan merek

\footnotetext{
${ }^{17}$ M. Yahya Harahap, Op. Cit., hal. 852.
} 
Penggugat secara tanpa hak dalam kaitannya dengan gugatan pelanggaran merek memiliki kemungkinan yang lebih besar untuk ditolak oleh hakim Pengadilan Niaga karena pertimbangan bahwa tindakan yang dimohonkan dalam provisi telah menyangkut pokok perkara.

\section{Saran}

Hendaknya dilakukan perubahan atas ketentuan mengenai penyelesaian sengketa pelanggaran merek di Pengadilan Niaga atau pembentukan peraturan perundangundangan mengenai Pengadilan Niaga yang dapat memaksimalkan perlindungan hukum bagi siapa saja yang berkepentingan untuk menyelesaikan sengketanya pada Pengadilan Niaga.

\section{DAFTAR PUSTAKA}

Asrun, Andi Muhammad, A.

Prasetyantoko, dkk , 2000, Analisa Yuridis dan Empiris

Peradilan Niaga, Centre for

Information \& Law - Economic

Studies (CINLES), Jakarta.

Harahap, M. Yahya, 2008, Hukum Acara

Perdata tentang Gugatan,

Persidangan, Penyitaan,

Pembuktian dan Putusan

Pengadilan, Cet. 8, Sinar Grafika, Jakarta
Machmudin, Dudu Duswara, 2010, Pengantar Ilmu Hukum: Sebuah Sketsa, Refika Aditama, Bandung.

Manan, Abdul, 2005, Penerapan Hukum Acara Perdata di Lingkungan Peradilan Agama, Kencana, Jakarta

Mertokusumo, Sudikno, 1982, Hukum Acara Perdata Indonesia, Liberty, Yogyakarta.

Muhammad, Abdulkadir, 2008, Hukum Acara Perdata Indonesia, PT Citra Aditya Bakti, Bandung.

Shubhan, M. Hadi, 2009, Hukum Kepailitan: Prinsip, Norma, dan Praktik di Peradilan, Kencana, Jakarta.

Waluyo, Bambang, 1991, Penelitian Hukum dalam Praktek, Sinar Grafika, Jakarta.

Widjaja, Gunawan, 2001, Undang-Undang Merek No. 15 Tahun 2001: Beberapa Hal Baru yang Diatur di Dalamnya, Law Review, Fakultas Hukum Universitas Pelita Harapan, Jakarta.

Wijayanta, Tata, 2009, Kajian tentang Kompetensi Absolut Pengadilan Niaga, Jurnal Ilmu Hukum Litigasi, Volume 10 Nomor 1 Pebruari 2009.

Biodata Penulis: 
Nama : Devi Marlita Martana

Alamat : Jl. Padang Tawang I/9, Canggu,

Kuta Utara, Badung.
No. Telp: 08990125873

E-mail :devi_marlita@yahoo.com 